\title{
Development of Smartphone-Based Early Alerts and Mosquito Monitoring System and Geographic InstrumentSystemApplications
}

\author{
Kartini Kartini*, Sofia Sofia, Nasrullah Nasrullah \\ Department of Environmental Health, Polytechnic of Health, Ministry of Health, Aceh, Indonesia
}

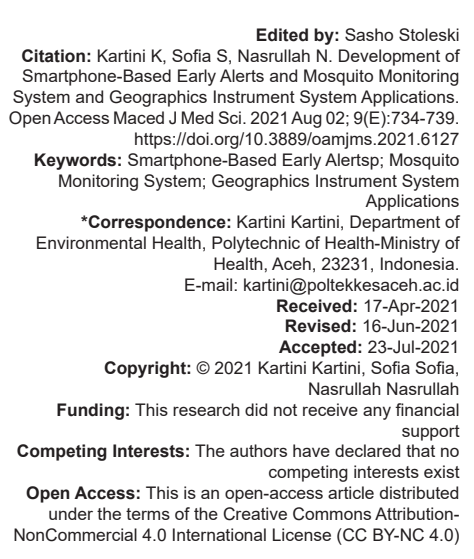

Introduction

Mosquito-borne diseases such as malaria have been a significant public health challenge for centuries, especially in humid subtropical zones [1]. Mosquitoborne diseases continue to burden human society and impede prosperity and economic development [2]. The number of Dengue hemorrhagic fever (DHF) cases fluctuates every year. Data from the Directorate for Prevention and Control of Vectorborne and Zoonotic Diseases, the Indonesian Ministry of Health, in 2014, the number of sufferers reached 100,347, 907 died. In 2015 , there were 129,650 cases and 1071 deaths. Meanwhile, in 2016 there were 202,314 sufferers and 1593 deaths. In 2017, from January to May, there were 17,877 cases, with 115 deaths [3]. The incidence rate (IR) in 34 provinces in 2015 reached 50.75 per 100 thousand population and IR in 2016 reached 78.85 per
100 thousand population. This figure is still higher than the national IR target of 49 per 100 thousand population.

Data from the Aceh Health Office in 2018 showed 1,533 cases of DHF in Aceh, and data from the Banda Aceh City Health Office showed an increase in DHF cases at the end of the year [4]. The trend of increasing cases is influenced by the peak of the rainy season, which occurs at the turn of the year. Humid climatic conditions and environmental temperatures that tend to be relaxed at the peak of the rainy season are very conducive to developing Aedes aegypti mosquito larvae. Apart from climate change, international trade and human transport are considered the main drivers of the entry of new vectors, with or without their pathogens, into different geographic areas [5]. Apart from climate, the increase in dengue fever is also influenced by population density. This can be seen from the areas where dengue is infected in Aceh Besar District, a 
densely populated area, including Darul Imarah District, Darul Kamal District, Simpang Tiga District, and Krueng Barona Jaya District. Various mosquito control programs have recently been implemented in response to an increased incidence of several diseases spread to humans through the bites of infected mosquitoes [6], [7].

The ability to detect early outbreaks is key to enhancing an adequate response. Early warning and response systems (EWARS) are tools that provide countries with an early warning system for an efficient and cost-effective local response [8]. The frequency and magnitude of dengue fever outbreaks have increased dramatically throughout the tropics in the past 40 years due to unplanned urbanization, globalization, and a lack of effective mosquito control [9]. Effective control of neglected tropical diseases with explosive outbreak dynamics, such as dengue fever, relies on timely analysis of collected surveillance data, and rapid response [10], [11], [12].

One of the practical disease control efforts in Geographics Instrument System (GIS) implementation and the online SMS mobile application. Implementing GIS in handling DHF cases is expected to increase decision-making effectiveness so that the resulting decisions are expected to be better. GIS is a system that can support a system in spatial decision-making and is able to integrate location descriptions with the characteristics of the phenomena found in a location. GIS data input can come from remote sensing data, field survey data, climatological data, demographic data, and socio-economic data. GIS remote sensing can assist health and development decision-making [13]. GIS mapping will facilitate instantaneous updating of information and identifying problem hotspots at the village level to formulate a cost-effective malaria control strategy [14]. The development of online applications allows any data generated at that time to be collected into the system. This system is expected to increase the knowledge/ability in the simple spatial field by utilizing smartphone technology and accelerating the data analysis process of $\mathrm{HI}, \mathrm{Cl}, \mathrm{BI}$, and ABJ. Given the importance of these problems to find a solution. An application is required for recording home visit data that can be brought directly by larva monitoring workers (Jumantik cadre) during the visit. Mobile applications can be a solution to the problems faced. Besides, the results of the visit data recap recorded on the Mobile Application by larva monitoring workers (Jumantik cadre) can be sent directly to the Health Service server. They created a survey system with a smartphone for early alertness to larva monitoring in the Darul Imarah sub-district, Aceh Besar district. Seeing the high number of DHF cases in Aceh Besar District, it is necessary to research the disease's early alert system.

\section{Methods}

We choose the descriptive quantitative research conducted by survey method. This research aims to create a survey system using a smartphone for early alertness to larva monitoring in the Darul Imarah sub-district, and Aceh Besar district. This study population was all larva monitoring workers in the District of Darul Imarah, Aceh Besar District. The research location is located in Darul Imarah District, Aceh Besar District. Primary data contain the value of the Container index $(\mathrm{CI})$, House index $(\mathrm{HI})$, and Breteau index $(\mathrm{BI})$. Secondary data were collected by tracing related research results as well as data available at the Public health center. The research stages include research preparation by doing licensing, Ethical Clearance Management, and Research Location Survey. Furthermore, the data collection stage includes data collection of DHF cases from the health center and data entry.

Then proceed with taking the coordinates of the research location and entering the $\mathrm{HI}$ and $\mathrm{Cl}$, and $\mathrm{BI}$ data. Data buffering, clustering, and kernel density are processed into GIS-based data - descriptive data analysis to describe the SmartPhone Link. Analytical Analysis of Research Instruments was carried out using the Geographical Instrument System (GIS) application, then the data $\mathrm{Cl}, \mathrm{HI}$, and $\mathrm{BI}$ checklists were carried out.

\section{Results}

\section{DHF case in darul imarah subdistrict}

The population in Darul Imarah District, Aceh Besar District in 2019 was 53,177, with 27,030 men and 26,147 women. The system for monitoring and data collection of mosquito larvae in the district has been done manually. The cadres who help voluntarily go around the residents' houses and check mosquito larvae in certain places. Data on DHF cases in Darul Imarah Subdistrict from 2018 to 2020 were received from the Darul Imarah District Health Center combined into one Table 1 below.

Based on Table 1, there were 16 cases of dengue fever in Darul Imarah Subdistrict in 4 villages, namely, Garot, Lagrange, Lampeuneurut Ujong Blang Tingkeum Villages. The highest cases of DHF in Darul ImarahDistrictoccurred in 2019, namely, 60 cases spread across 13 villages, including Garot Village, Kandang Village, Lagang Village, Lambheu Village, Lamblang Manyang Village, Lampeuneun Village, Lampeuneurut Ujong Blang Village, Lamreung Village, Desa Lamsiteh, 
Table 1: Data on the Number of DHF Cases in Darul Imarah subdistrict from 2018 to 2020 comes from the Darul Imarah Health Center

\begin{tabular}{lllll}
\hline No & Name Villages & \multicolumn{3}{l}{ Year DHF Case } \\
\cline { 3 - 5 } & & 2018 & 2019 & 2020 \\
\hline 1 & Bayu & - & - & - \\
2 & Daroy Kameu & - & - & - \\
3 & Denong & - & - & - \\
4 & Garot & 5 & 7 & 2 \\
5 & Gendring & - & - & - \\
6 & Gue Gajah & - & - & 2 \\
7 & Jeumpet & - & - & 2 \\
8 & Kandang & - & 1 & - \\
9 & Kuta Karang & - & - & - \\
10 & Lagang & 4 & 4 & - \\
11 & Lambheu & - & 5 & - \\
12 & Lamblang Manyang & - & 3 & - \\
13 & Lamblang Trieng & - & - & - \\
14 & Lamkawe & - & - & - \\
15 & Lamcot & - & - & - \\
16 & Lampasi Engking & - & - & - \\
17 & Lampeuneun & - & 5 & - \\
18 & Lampeuneurut Gampong & - & - & - \\
19 & Lampeuneurut Ujong Blang & 2 & 3 & - \\
20 & Lamreung & - & 6 & - \\
21 & Lamsidaya & - & - & - \\
22 & Lamsiteh & - & 4 & - \\
23 & Lamtheun & - & - & - \\
24 & Leu ue & - & - & 2 \\
25 & Leugeu & - & - & - \\
26 & Lheu Blang & - & - & - \\
27 & Pasi Betong & - & 5 & - \\
28 & Payaroh & - & - & - \\
29 & Puni & - & - & - \\
30 & Tingkeum & - & 5 & - \\
31 & Ulee Tuy & - & - & - \\
32 & Ulee Lueng & & - & - \\
Total & & - & - & - \\
\hline & & - & - & - \\
\hline
\end{tabular}

Pasi Betong Village, Tingkeum Village, Ulee tuy Village, and Ulee Leung Village. Meanwhile, dengue cases in 2020 have decreased so that the number of cases in 2020 in 13 cases spread across seven villages, including Garot, Gue Gajah, Jumper, Leu use, Tingkeum, Ulee Tuy, and Ulee Leung Villages. Larva monitoring cases were carried out in several villages that had suffered from dengue in 2019. The distribution of dengue cases from 2018 to 2020 can be seen in the form of a map. The map of the spread of dengue cases in 2018 is shown in Figure 1, while the map of the spread of dengue cases in 2019 can be seen in Figure 2, and the map of the spread of dengue cases in 2020 can be seen in Figure 3.

Figure 3 shows where the points of DHF cases in 2018 in each village of Darul Imarah District; among others, in Garot Village, there were five cases, in Lagrange Village 4 cases, in Lampeuneurut village Ujong Blang two cases and Tingkeum Village five cases.

Figure 1 shows where the points of DHF cases in 2019 are in each village of Darul Imarah District, among others, in Garot Village there were seven cases, in Kandang Village one case, in Lagang Village 4 cases, Lambheu Village five cases, in Lamblang Manyang Village three cases, in Lampeuneun Village five cases, in Lampeuneurut Ujong Blang Village three cases, six cases in Lamreung Village, four cases in Lamsiteh Village, five cases in Pasi Betong Village, 11 cases in Tingkeum Village, five cases in Ule Tuy Village, and Ulee Leung Village 1 case.

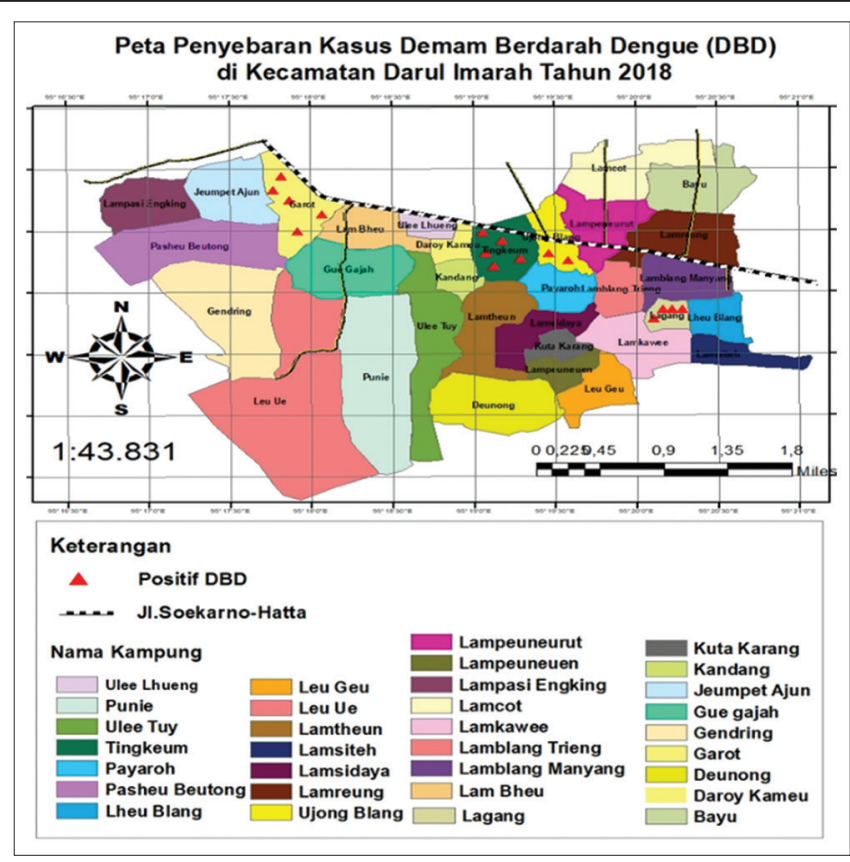

Figure 1: Picture of the map of the distribution of dengue hemorrhagic fever cases in Darul Imarah District in 2018

Figure 2 shows where the points of DHF cases in 2020 are in each village of Darul Imarah District, among others in Garot Village, there were two cases, two cases in Gue Gajah Village, two cases in Jeumpet Village, two cases in Leu ue Village, in Tingkeum Village one case, two cases in Ulee Tuy Village, and two cases in Ulee Leung Village.

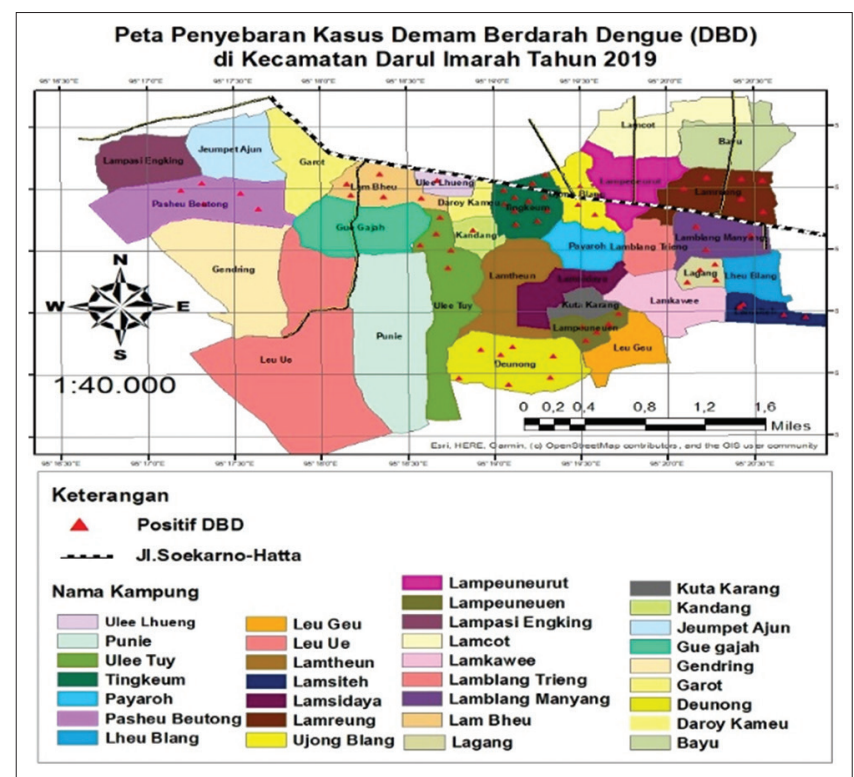

Figure 2: Map of the distribution of dengue hemorrhagic fever cases in Darul Imarah District in 2019

\section{Density figure figure}

Based on the results of the Aedes aegypti mosquito larva density survey conducted in the Darul Imarah sub-district, Aceh Besar district at 120 houses, the following results were obtained: 


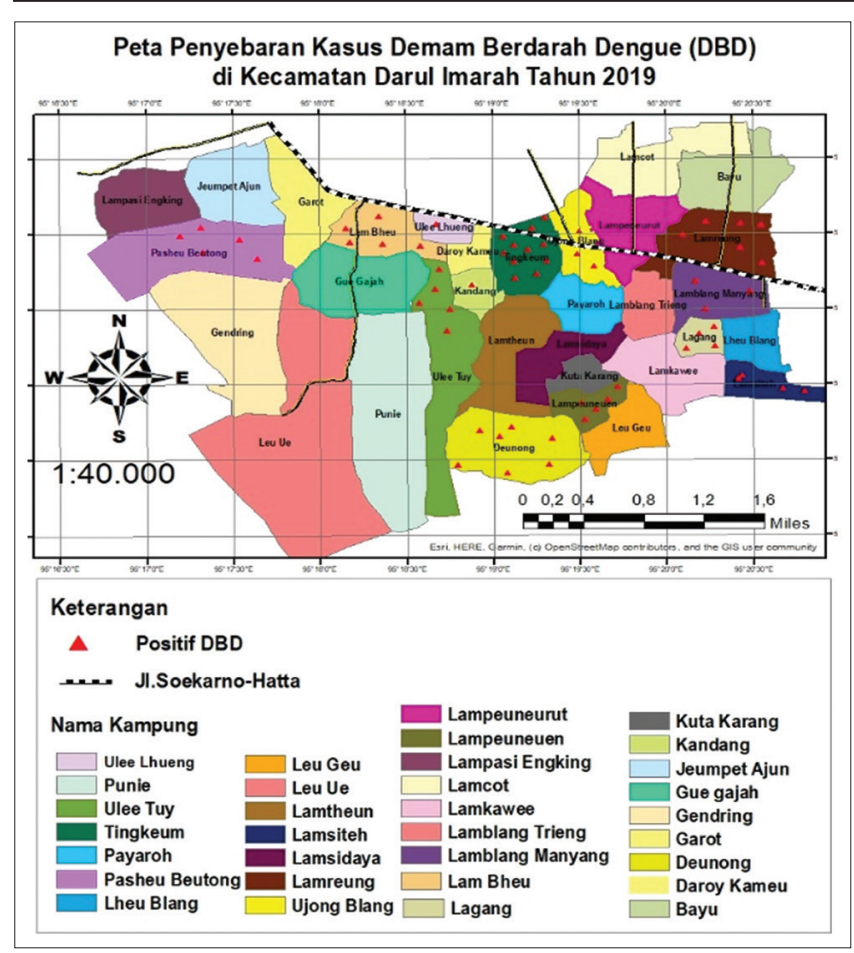

Figure 3: Map of the distribution of dengue hemorrhagic fever cases in Darul Imarah district in 2020

Based on Table 2 above, it is known that of the 120 houses that were inspected for larvae, 74 houses were positive for larvae, while 46 houses were negative for larvae. The number of containers inspected from 120 houses was 502, with the results that 309 houses were found to be larvae and 193 houses were not found. From Table 2 above, it is also known that the HI

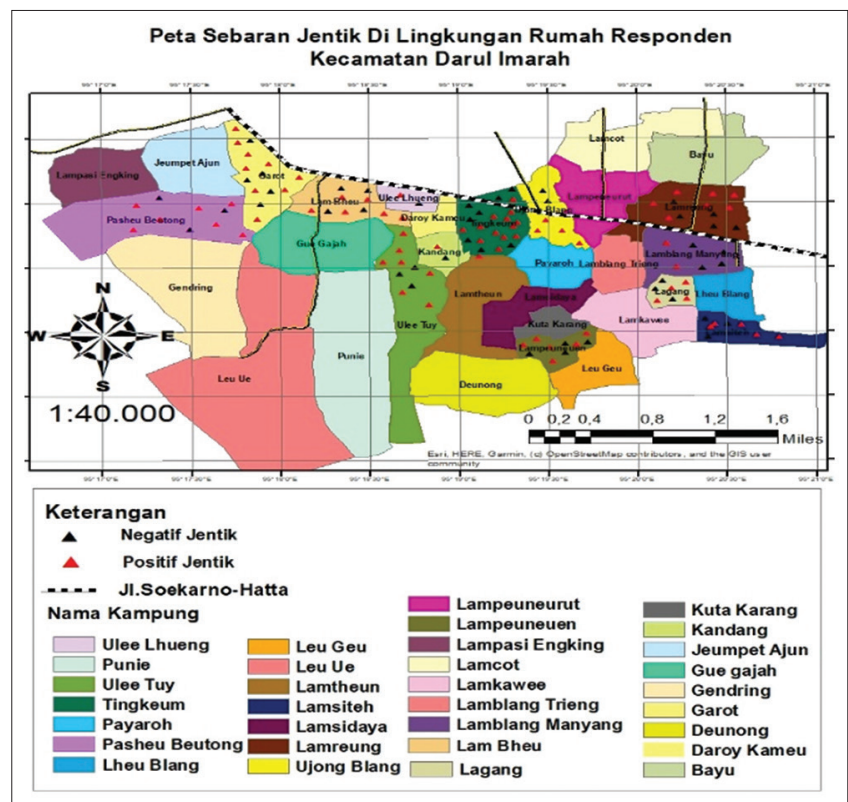

Figure 4: Distribution of larvae in the respondent environment in Darul Imarah District

value is $62 \%$, the $\mathrm{Cl}$ value is $61 \%$, the $\mathrm{BI}$ value is $103 \%$, and the ABJ value obtained is $38.3 \%$. Based on these results, it is known that the density figure level is at the larva density level, which is included in the high-density category. The overall distribution of larvae from the environment of positive and negative larva respondents in Darul Imarah District can be seen in the form of a map in Figure 1.

From the monitoring of larvae, the number of cheerful houses for Aedes aegypti mosquito larvae was 74 houses, while the number of damaging houses for Aedes aegypti mosquito larvae was 46 houses.

Table 2: Results of the Aedes aegypti mosquito larva density survey

\begin{tabular}{lllllllll}
\hline No & Checked & Amount & larva & $\mathrm{HI}(\%)$ & $\mathrm{Bl}(\%)$ & $\mathrm{Cl}(\%)$ & $\mathrm{ABJ}(\%)$ \\
\cline { 3 - 6 } & & & Yes & No & & & & \\
\hline 1 & House & 120 & 74 & 46 & $62 \%$ & $61 \%$ & $103 \%$ & $38,3 \%$ \\
2 & Container & 502 & 309 & 193 & & & & \\
\hline
\end{tabular}

The results of the mapping (Figure 1) show positive and negative house points for larvae from each village that has been checked; the points for cheerful houses include, in Garot Village consisting of nine houses, Kandang village consisting of one house, in Lagang Village consisting of five houses, Lambheu Village consists of six houses, in Lamblang Manyang Village consists of two houses, and in Lampeuneun. The village consists of six houses, in Lampeuneurut Ujong Blang Village consists of four houses, in Lamreung Village consists of seven houses, in Lamsiteh Village consists of five houses, in Pasi Village Betong consists of seven houses, in Tingkeum Village it consists of 14 houses, in Ule Tuy Village it consists of seven houses. Ulee Leung Village consists of one house. Whereas the negative house points are negative larvae from each village examined include, Garot Village which consists of five houses, Kandang village consists of one house, Lagang Village consists of three houses, Lambheu Village consists of four houses, in Lamblang Manyang Village consists of four houses, in Lampeuneun Village consisting of four houses, in Lampeuneurut Ujong Blang village consisting of two houses, in Lamreung Village consisting of five houses, in Lamsiteh Village consisting of three houses, in Pasi Betong Village consisting of three houses, in Tingkeum Village consisting of eight houses, in Desa Ule Tuy consists of three houses, and in Ulee Leung the village consists of one house. Then in this study, monitoring of larvae was carried out in several containers such as drums, bathtubs, buckets, water reservoirs, dispensers, refrigerator water reservoirs, used tires, Aqua glasses, and other containers that have clean water without frequently draining. From the monitoring of larvae in Table 2 above, the total number of positive containers for Aedes aegypti mosquito larvae is 309. While the total number of negative containers is larvae, Aedes aegypti mosquitoes were 193. The total number of containers examined from 120 houses was 502 containers.

\section{Survey smartphone}

The larva density survey was carried out using Google form by providing the following link: https://forms.gle/vEQMp7hRPrXejYCF6 to the larva monitoring cadres each village selected as samples. 
Previously, cadres were given training on how to use Google form links. The data from the field survey were then transferred to the research data management center for further tabulation. Then, on the map, the coordinate points' location, where when choosing the button, take the coordinates, the latitude and longitude coordinates will appear.

\section{Discussion}

In general, Darul Imarah District is a rural area, so that environmental problems, especially those related to vector-borne diseases, are often a problem due to the lack of knowledge and behavior of the community. DHF is one of the diseases caused by the dengue virus, carried by a vector, namely, the Aedes Aegyptus mosquito. DBD Cases in Darul Imarah District, data on dengue cases in Darul Imarah Subdistrict from 2018 to 2020 was received from the Darul Imarah District Health Center. The Aedes aegypti mosquito larva density survey results show that of the 120 houses that were inspected for larvae, 74 houses were positive for larvae, while 46 houses were negative for larvae. The number of containers inspected from 120 houses was 502, with the results that 309 houses were found to be larvae and 193 houses were not found. The $\mathrm{Cl}$ is $61 \%$, the $\mathrm{HI}$ is $62 \%$, the $\mathrm{BI}$ is $103 \%$, and the $\mathrm{ABJ}$ value obtained is $38.3 \%$. A buffer analysis in the $50-\mathrm{m}$ zone from the house of a dengue case sufferer shows that mosquitoes originating from the house of a dengue case sufferer are a risk factor that results in dengue transmission because two cases in 2019 are included in the buffer zone. The analysis results showed that the locations of DHF cases found in Lamsiteh Village, Darul Imarah District, each were at a distance of $50 \mathrm{~m}$. Buffer in the zone $100 \mathrm{~m}$ from the patient's house; the Aedes aegypti mosquito can cause dengue fever cases because as many as 24 dengue cheerful houses are in the buffer zone. The analysis results showed DHF cases found in Lamsiteh Village, Lagrange, Lampeuneun, Tingkeum, Deunong, and Lambeau. Based on the research results, the transmission of dengue disease does not recognize regional boundaries. The Darul Imarah sub-district government needs to be aware of the risk of dengue fever outbreaks in the region and needs to make efforts to prevent dengue transmission. Gampong Lheu Blang, Lamkawe, Lamblang Trieng, Lampeneurut, Lamcot, Bayu, Payaroh, Lamsidaya, Leu Geu, Kuta Karang, Lamtheun, Punie, Leu ue, Gendring, Garot, Jeumpet Ajun, Gur Gajah, and Lampasie which are within a safe radius of infection DHF disease. Mobile electronic data retrieval is a fast-growing information technology with great potential to be incorporated into data management systems and decision support systems to successfully transfer data collected in the field into the system [15]. Knowledge about dengue is very important as a preventive effort. Public health policies aimed at combating these vectors require reliable and timely information, which is usually expensive to obtain with field campaigns [16] prevention information system and public education in handling endemic. Web-based infectious and non-communicable diseases for the improvement of public health can collect, manage, and visualize data and information in the form of a web for the public regarding knowledge of infectious and non-communicable diseases (educating) the causes, modes of transmission, and methods of prevention as well as mapping the location of health center [17]. GIS spatial analysis skills can help Evaluates the complex relationship of information to support environmental and health-related policies and regulations [18]. Citizen involvement in using an Android-based smartphone application to inform health authorities about breeding places using interactive forms and social media. The advancement of smartphones based on Android and better internet coverage can track breeding places to be recorded more quickly. The socialization results show that the mobile GIS application can help health institutions in taking preventive measures for dengue fever early because the information in the form of excel files can be transferred online through a smartphone.

\section{Conclusion}

Darul Imarah subdistrict has an area prone to dengue cases. From the survey results, it is known that the density figure is in the category of high larva density. In a zone $50 \mathrm{~m}$ from the house of a dengue case sufferer, indicating that mosquitoes originating from the house of the dengue case sufferer are a risk factor that results in dengue transmission Monitoring larvae in the Darul Imarah sub-district, it is known that of the 120 houses that were inspected for larvae, 74 houses were positive for larvae. In contrast, 46 houses were negative for larvae.

\section{References}

1. Moreno-Madriñán $\mathrm{MJ}$, Turell $\mathrm{M}$. History of mosquitoborne diseases in the united states and implications for new pathogens. Emerg Infect Dis. 2018;24(5):821-6. https://doi:10.3201/ eid2405.171609 PMid:29664379

2. Murray CJ, Rosenfeld LC, Lim SS, Andrews KG, Foreman KJ, Haring D, et al. Global malaria mortality between 1980 and 2010: A systematic analysis. Lancet. 2012;379(9814):413-31. https://doi:10.1016/S0140-6736(12)60034-8

PMid:22305225

3. Kementerian Kesehatan RI. Kendalikan DBD Dengan PSN 3M 
Plus. Jakarta: Kementerian Kesehatan RI; 2016.

4. Dinkes Provinsi Aceh. Profil Kesehatan 2019 Provinsi Aceh. Aceh; 2019.

5. Caminade C, Kovats S, Rocklov J, Tompkins AM, Morse AP, Colón-González FJ, et al. Impact of climate change on global malaria distribution. Proc Natl Acad Sci U S A. 2014;111(9):328691. https://doi:10.1073/pnas.1302089111 PMid:24596427

6. Gubler DJ. The global emergence/resurgence of arboviral diseases as public health problems. Arch Med Res. 2002;33(4):330-42. https://doi:10.1016/s0188-4409(02)00378-8 PMid:12234522

7. Fouet C, Kamdem C. Integrated mosquito management: Is precision control a luxury or necessity? Trends Parasitol. 2019;35(1):85-95. https://doi:10.1016/j.pt.2018.10.004 PMid:30446394

8. Hussain-Alkhateeb L, Kroeger A, Olliaro P, Rocklöv J, Sewe MO, Tejeda G, et al. Early warning and response system (EWARS) for dengue outbreaks: Recent advancements towards widespread applications in critical settings. PLoS One. 2018;13(5):e0196811. https://doi:10.1371/journal.pone.0196811

PMid:29727447

9. Msellemu D, Gavana T, Ngonyani H, Mlacha YP, Chaki P, Moore SJ. Knowledge, attitudes and bite prevention practices and estimation of productivity of vector breeding sites using a habitat suitability score (HSS) among households with confirmed dengue in the 2014 outbreak in Dar es Salaam, Tanzania. PloS Negl Trop Dis. 2020;14(7):e0007278 https:// doi:10.1371/journal.pntd.0007278

PMid:32614855

10. Kan CC, Lee PF, Wen TH, Chao DY, Wu MH, Lin NH, et al. Two clustering diffusion patterns identified from the 2001-2003 dengue epidemic, Kaohsiung, Taiwan. Am J Trop Med Hyg. 2008;79(3):344-52.

PMid: 18784225

11. Jeefoo P, Tripathi NK, Souris M. Spatio-temporal diffusion pattern and hotspot detection of dengue in Chachoengsao Province, Thailand. Int J Environ Res Public Health. 2011;(1):51-74. https://doi:10.3390/ijerph8010051

PMid:21318014

12. Vazquez-Prokopec GM, Kitron $U$, Montgomery B, Horne $P$, Ritchie SA. Quantifying the spatial dimension of dengue virus epidemic spread within a tropical urban environment. PLoS Negl Trop Dis 2010;4(12):920. https://doi.org/10.1371/journal. pntd.0000920

13. Hassan AN, Onsi HM. Remote sensing as a tool for mapping mosquito breeding habitats and associated health risk to assist control efforts and development plans: A case study in Wadi EI Natroun, Egypt. J Egypt Soc Parasitol. 2004;34(2):367-82. PMid:15287164

14. Srivastava A, Nagpal BN, Joshi PL, Paliwal JC, Dash AP. Identification of malaria hot spots for focused intervention in tribal state of India: A GIS based approach. Int J Health Geogr. 2009;8:30. https://doi:10.1186/1476-072X-8-30 PMid:19457227

15. Lozano-Fuentes S, Wedyan F, Hernandez-Garcia E, Sadhu D, Ghosh S, Bieman JM, et al. Cell phone-based system (Chaak) for surveillance of immatures of dengue virus mosquito vectors. J Med Entomol. 2013;50(4):879-89. https://doi:10.1603/ me13008 PMid:23926788

16. Scavuzzo JM, Trucco F, Espinosa M, Tauro CB, Abril M, Scavuzzo CM, et al. Modeling Dengue vector population using remotely sensed data and machine learning. Acta Trop. 2018;185:167-75. https://doi:10.1016/j. actatropica.2018.05.003 PMid:29777650

17. Setiawan TA, llyas A, A. P. W. Pencegahan dan edukasi masyarakat dalam penanganan endemik penyakit berbasis web untuk peningkatan kesehatan masyarakat di kota pekalongan. J Litbang Kota Pekalongan. 2018;15:35-42.

18. Blanco GA, Cooper EL. Immune systems, geographic information systems (GIS), environment and health impacts. J Toxicol Environ Health B Crit Rev. 2004;7(6):465-80. https:// doi:10.1080/10937400490512375

PMid: 15586880 